\title{
HUBUNGAN ANTARA STADIUM KANKER PAYUDARA DENGAN TINGKAT DEPRESI PADA PASIEN KANKER PAYUDARA
}

\author{
Correlation Between Breast Cancer Stage with Depression Levels in Breast Cancer \\ Patient
}

\author{
I Putu Artha Wijaya ${ }^{1}$, Ni Nyoman Suardani ${ }^{1}$, AA Ngr Bayu Bhaskara ${ }^{2}$ \\ ${ }^{1}$ Departemen Keperawatan Medikal Bedah, STIKES Bina Usada Bali, Badung, Bali, Indonesia \\ 2,Mahasiswa Pogram Studi S1 Keperawatan, STIKES Bina Usada Bali, Badung, Bali, Indonesia
}

\begin{abstract}
ABSTRAK
Kanker payudara merupakan penyakit yang tidak menular yang paling banyak menyerang wanita, penyakit kanker payudara jenis kanker yang paling mendominasi di Indonesia sebesar $30 \%$ yang mengalahkan kanker serviks yang berkontribusi sebesar $24 \%$. Beberapa faktor yang memengaruhi depresi pada pasien kanker yaitu terkait penyakit (lama diagnosis, tingkat keparahan, prognosis yang buruk, dan rasa sakit), dari internal pasien itu sendiri (ketakutan akan rasa sakit, mati, kehilangan kontrol dan kemandirian, merasa tidak berdaya), penanganan (efek samping terapi, lama penanganan, perawatan berulang, mahalnya biaya). Adapun tujuan dari penelitian adalah untuk mengetahui hubungan antara stadium kanker payudara dengan tingkat depresi pada pasien kanker payudara. Penelitian ini menggunakan metode penelitian kuantitatif dengan metode penelitian cross sectional. Teknik pengambilan sampel menggunakan non probability sampling yaitu purposive sampling dengan jumlah sampel sebanyak 121 responden. Instrumen penelitian ini menggunakan kuesioner Beck Depression Inventory II (BDI II). Analisia data menggunakan uji korelasi rank spearman. Hasil analisa data diperoleh nilai koefisien korelasi (r) 0,366 menunjukkan arah dan kekuatan hubungan yang berarti kedua variabel memiliki hubungan yang cukup kuat dengan arah hubungan positif. Dapat disimpulkan bahwa semakin berat stadium kanker, maka semakin berat pula gejala depresi yang dialami.
\end{abstract}

Kata Kunci : tingkat depresi, stadium kanker payudara

\section{ABSTRACT}

Breast cancer is a non-communicable disease that mostly attacks women, breast cancer is the most dominant type of cancer in Indonesia by $30 \%$ which beats cervical cancer which contributes by $24 \%$. Several factors that influence depression in cancer patients are related to the disease (duration of diagnosis, severity, poor prognosis, and pain), from the patient's internal self (fear of pain, death, loss of control and independence, feeling helpless), treatment (side effects of therapy, duration of treatment, repeated treatments, high costs). The purpose of the study was to determine the correlation between breast cancer stage with depression levels in breast cancer patients. This research uses quantitative research methods with cross sectional research methods. The sampling technique uses non probability sampling that is purposive sampling with a total sample of 121 respondents. This research instrument used the Beck Depression Inventory II (BDI II) questionnaire. Data analysis used spearman rank correlation test. The results of data analysis obtained the value of the correlation coefficient (r) 0.366 indicates the direction and strength of the relationship which means that the two variables have a strong enough relationship with the direction of a positive relationship. It can be concluded that the more severe the stage of the cancer, the more severe the symptoms of depression that are experienced.

Keywords: levels of depression, stage breast cancer 
I Putu Artha Wijaya: Hubungan Antara Stadium Kanker Payudara Terhadap Tingkat Depresi Pada Penderita Kanker Payudara Di Rsup Sanglah

\section{PENDAHULUAN}

Kanker payudara merupakan penyakit yang tidak menular yang paling banyak menyerang wanita, penyakit kanker payudara jenis kanker yang paling mendominasi di Indonesia sebesar 30\% yang mengalahkan kanker serviks yang berkontribusi sebesar 24\% (Irawan, 2017). Di Indonesia, jumlah kasus terjadinya kanker payudara menduduki urutan pertama, yaitu sebanyak 18,4\%. Di Jawa Timur, kasus kanker payudara menduduki urutan kedua terbanyak setelah Jawa Tengah, yaitu 9.658 orang (Hariroh, 2017).

Sebagian besar kasus kanker payudara pada usia muda adalah dengan stadium stadium lanjut (stadium III dan stadium IV). Kategori stadium awal (I, IIA, IIB, IIIA) dan stadium lanjut (IIIB, IIIC dan IV) (Hartaningsih, 2012). Angka kejadian penyakit kanker payudara Di RSUP Sanglah tahun 2015 sebesar 1.289 orang, tahun 2016 sebesar 1.247 orang, tahun 2017 sebesar 1.416 orang, sedangkan pada tahun 2018 dari bulan januari sampai bulan juni sebesar 1.088 orang. Kejadian kanker payudara di RSUP Sanglah mengalami kenaikan dan penurunan setiap tahunnya.

Beberapa faktor yang memengaruhi depresi pada pasien kanker yaitu terkait penyakit (lama diagnosis, tingkat keparahan, prognosis yang buruk, dan rasa sakit), dari internal pasien itu sendiri (ketakutan akan rasa sakit, mati, kehilangan kontrol dan kemandirian, merasa tidak berdaya), penanganan (efek samping terapi, lama penangganan, perawatan berulang, mahalnya biaya), dan tim medis (kurangnya komunikasi dan informasi) (Widiyono, 2017). Pada penderita kanker payudara stadium lanjut/akhir akibat perjalanan penyakit yang buruk dan efek samping pengobatan dapat mempengaruhi kondisi psikologis pasien yang dapat menyebabkan depresi. Gejala-gejala umum depresi yang terjadi pada penderita kanker payudara seperti perasaan sedih, rasa putus asa, hilangnya nafsu makan, dan perasaan kecewa.

Hasil penelitian Hartaningsih dan Sudarsa (2014) di Rumah Sakit Umum Pusat Sanglah Denpasar, menunjukkan presentase penderita kanker payudara stadium lanjut pada wanita usia muda ( $<40$ tahun) tahun 2002-2012 sebesar 79,5\% (158 orang) dan bila dilihat dari keseluruhan kelompok umur terbanyak yaitu 40-50 tahun sebesar 45,2\% (396 orang) (Dyanti, 2016). Angka kejadian penderita kanker payudara di RSUP Sanglah dari tahun 2015 sampai tahun 2018 lebih dari 1.000 pasien yang berobat maupun yang menjalani rawat inap di RSUP Sanglah, dikarenakan RSUP Sanglah merupakan rumah sakit umum pusat yang menjadi rumah sakit rujukan untuk Bali, NTT, NTB, dan Timor Timur.

Menurut Hariroh (2017) Ketika seseorang terdiagnosis kanker, pada umumnya akan merasakan distres emosional yang sangat berat seperti shock, cemas, dan depresi. Prevalensi gejala depresi pada pasien dengan kanker payudara adalah $4,94 \%$. Hubungan antara gejala depresi dengan kanker payudara adalah kontribusi dari berbagai aspek, salah satunya karena prognosis yang buruk (stadium). Perubahan pada pasien kanker payudara stadium lanjut akibat perjalanan penyakit yang kronik dan efek samping pengobatan dapat memengaruhi penilaian negatif pasien terhadap dirinya sendiri yang dapat menyebabkan perasaan depresi.

\section{TUJUAN PENELITIAN}

Penelitian ini bertujuan untuk mengetahui hubungan antara stadium kanker payudara dengan tingkat gejala depresi pada penderita kanker payudara di RSUP Sanglah.

\section{METODE PENELITIAN}

Desain

Penelitian ini merupakan penelitian deskriptif korelasional dengan menggunakan pendekatan cross sectional.

\section{Populasi dan Sampel}

Populasi pada penelitian ini adalah seluruh pasien kanker payudara yang dirawat di RSUP Sanglah. Jumlah sampel dalam penelitian ini sebanyak 121 responden. Tehnik pengambilan sampel menggunakan non probability sampling jenis purposive sampling sesuai dengan kriteria inklusi, yaitu pasien yang terdiagnosis mengalami kanker payudara 
I Putu Artha Wijaya: Hubungan Antara Stadium Kanker Payudara Terhadap Tingkat Depresi Pada Penderita Kanker Payudara Di Rsup Sanglah

dan penderita kanker payudara yang bersedia menjadi responden.

\section{Tempat dan Waktu Penelitian}

Penelitian ini dilakukan ruangan rawat inap dan di poliklinik bedah onkologi RSUP Sanglah. Pengambilan data dilakukan selama 4 minggu.

\section{Instrumen dan Prosedur Pengukuran}

Instrumen yang digunakan dalam penelitian ini adalah kuesioner Beck Depression Inventory II (BDI-II). Kuesioner ini terdiri dari 21 item pernyataan akan diberikan setelah calon responden memenuhi kriteria inklusi.

\section{Analisa Data}

Analisa data dilakukan dengan menggunakan uji chi square untuk pengukuran korelasi variabel independen dengan variabel dependen. Analisa univariat dilakukan pada data karakteristik responden.

\section{HASIL PENELITIAN} berikut :

Hasil penelitian ini disajikan sebagai

Tabel 1.

Karakteristik Respoden $(\mathrm{n}=121)$

\begin{tabular}{lcccccc}
\hline \multicolumn{1}{c}{ Variabel } & n & \% & Min & Max & Mean & SD \\
\hline Usia & & & 25 & 76 & 51.44 & 9.423 \\
\hline Tingkat & & & & & & \\
Pendidikan & & & & & & \\
Tidak & & & & & & \\
Sekolah & 4 & 3 & & & & \\
SD & 38 & 31 & & & & \\
SMP & 13 & 11 & & & & \\
SMA & 46 & 38 & & & & \\
PT & 20 & 17 & & & & \\
\hline Pekerjaan & & & & & & \\
Tidak & & & & & & \\
Bekerja & 1 & 1 & & & & \\
IRT & 82 & 68 & & & & \\
Petani & 2 & 2 & & & & \\
Pedagang & 8 & 6 & & & & \\
Swasta & 26 & 21 & & & & \\
Guru & 2 & 2 & & & & \\
\hline Stadium & & & & & \\
Kanker & & & & & & \\
Stadium II & 31 & 26 & & & & \\
Stadium III & 79 & 65 & & & \\
Stadium IV & 11 & 9 & & & \\
\hline
\end{tabular}

\begin{tabular}{lll}
\hline $\begin{array}{l}\text { Stadium } \\
\text { Depresi } \\
\text { Tidak ada }\end{array}$ & & \\
gejala & 66 & 55 \\
$\begin{array}{l}\text { Gejala } \\
\text { ringan }\end{array}$ & 43 & 35 \\
$\begin{array}{l}\text { Gejala } \\
\text { sedang }\end{array}$ & 8 & 7 \\
$\begin{array}{l}\text { Gejala } \\
\text { berat }\end{array}$ & 4 & 3 \\
\hline
\end{tabular}

Tabel 1 menunjukkan bahwa rerata usia responden pada penelitian ini adalah 51,44 tahun dengan usia responden tertinggi adalah usia 76 tahun dan usia terendah adalah 25 tahun. Sebagian besar tingkat pendidikan responden adalah SMA/SMK, yaitu sebanyak 46 responden (38\%). Selain itu, sebagian besar responden bekerja sebagai IRT, yaitu sebanyak 82 responden (68\%). Stadium kanker responden berada pade stadium III, yaitu sebanyak 79 responden dengan persentase sebesar 65,3\%. Sebagian besar responden tidak menunjukkan adanya gejala depresi, yaitu sebanyak 66 responden dengan persentase sebesar $54,5 \%$.

Hasil uji bivariat akan disajikan hasil analisa hubungan stadium kanker payudara dengan tingkat depresi pada penderita kanker payudara di RSUP Sanglah. Hasil analisis bivariat dengan uji Rank Spearman akan ditampilkan pada tabel 2 .

\section{Tabel 2}

Analisa Hubungan Stadium Kanker Payudara Dengan Tingkat Depresi

\begin{tabular}{ccc}
\hline \multicolumn{1}{c}{ Variabel } & p-value & $\begin{array}{c}\text { Koefesien } \\
\text { Korelasi }\end{array}$ \\
\cline { 2 - 2 } $\begin{array}{c}\text { Stadium } \\
\text { Kanker } \\
\text { Tingkat } \\
\text { Depresi }\end{array}$ & 0.000 & 0.366 \\
\hline
\end{tabular}

Nilai $p$-value $=0,000(\mathrm{p} \leq 0,05)$ yang berarti ada hubungan stadium kanker payudara dengan tingkat depresi pada penderita kanker payudara di RSUP Sanglah. Nilai koefisien korelasi (r) 0,366 menunjukkan arah dan kekuatan hubungan yang berarti kedua variabel memiliki hubungan yang cukup kuat. 
I Putu Artha Wijaya: Hubungan Antara Stadium Kanker Payudara Terhadap Tingkat Depresi Pada Penderita Kanker Payudara Di Rsup Sanglah

\section{PEMBAHASAN}

Kanker payudara terdiri dari empat stadium yang dapat disebabkan karena berbai faktor seperti usia, status perkawinan, paritas, riwayat menstruasi, riwayat keluarga dan pajanan radiasi (Olfah, 2013). Teori tersebut sejalan dengan pendapat Sari (2016) yang mengungkapkan bahwa kanker payudara merupakan salah satu tumor ganas pada payudara yang berasal dari kelenjar, saluran kelennjar dan jaringan penunjang payudara. Kanker payudara yang banyak dialami oleh wanita sering menunjukkan diagnosis keparahan yang sudah lanjut (stadium III hingga IV) pada penegakan diagnosis pemeriksaan.

Widiyono (2017) mengungkapkan bahwa depresi pada penderita kanker dapat dipengaruhi oleh faktor penyakit, faktor internal pasien, penanganan dan peranan tim medis. Mekanisme terjadinya stres pada pada pasien ca mammae itu sendiri dapat di pengaruhi oleh mekanisme koping pasien yang merupakan cara yang dapat dilakukan untuk menyelesaikan masalah, menyesuaikan diri terhadap perubahan, serta berespon terhadap situasi yang mengancam (Keliat \& Akemat, 2010).

Temuan pada penelitian ini sejalan dengan penelitian Sukma (2018) yang menyatakan bahwa penderita kanker payudara di Rumah Sakit Tingkat III Baladhika Husada Jember lebih banyak yang tidak menunjukkan adanya gejala depresi, yaitu sebanyak 62 responden $(75,6 \%)$. Tingkat depresi yang dialami pasien dapat terjadi karena responden memiliki koping dan manajemen stres yang baik. Hal ini ditunjukkan melalui hasil jawaban responden pada kuesioner Beck Depression Inventory II (BDI-II) didapatkan bahwa responden tidak mengalami perubahan pada segala sesuatu yang diinginkan seperti perasaan berkecil hati terhadap masa depan, perasaan bersalah, perasaan kecewa dan tidak pernah memiliki keinginan untuk mengakhiri hidupnya terkait penyakit yang dihadapinya saat ini.

Reaksi psikologis pasien kanker payudara stadium lanjut lebih besar dibandingkan pada penderita kanker stadium awal. Kanker pada stadium lanjut menunjukkan bahwa adanya metastase sel abnormal ke jaringan dan organ lain. Hal ini membuat penderita kanker mengalami beberapa perubahan-perubahan baik secara fisik maupun psikologis yang memberikan penilaian negatif pada diri sendiri. Penilaian negatif, pesimistis, perasaan tidak berharga inilah yang selanjutnya mengarah pada keadaan depresi (Gabard, 2010).

Temuan dalam penelitian ini sesuai dan didukung oleh penelitian yang dilakukan Sari (2014) yang menyatakan bahwa stadium kanker payudara memiliki hubungan dengan depresi di RSUD dr. Zainoel Abidin Banda Aceh dengan nilai pvalue 0,012. Penelitian ini juga sejalan dengan penelitian yang dilakukan oleh Uila (2009) yang menyatakan bahwa ada pengaruh stadium kanker terhadap tingkat depresi ditunjukkan nilai $\mathrm{p}=0,015<0,05$. Penelitian ini sejalan dengan penelitian Jehn, Flath, Strux, Krebs, Possinger, Pezzutto, \& Lüftner (2012) yang menyatakan bahwa perkembangan tumor (metastase kanker) secara independen terkait dengan klinis dengan depresi $(p<0,001)$.

\section{KESIMPULAN}

Implikasi

Dapat disimpulkan pada penelitian ini terdapat hubungan positif yang mengindikasikan bahwa semakin berat stadium kanker, maka semakin berat pula gejala depresi yang dialami. Berdasarkan temuan pada penelitian ini, mengindikasikan stadium kanker dapat berperan dalam terjadinya depresi pada penderita kanker karena adanya respon emosional dan persepsi pasien terhadap penyakitnya. Persepsi yang buruk pada kondisi kesehatan dapat mempengaruhi munculnya respon emosional seperti adanya perasaan cemas dan takut. Pikiran dan perasaan yang tidak dapat dikendalikan yang disebabkan koping individu yang buruk serta kurangnya dukungan orang sekitar dapat menimbulkan terjadinya kondisi depresi pasien pada kondisi kesehatannya.

\section{Keterbatasan}

Pada penelitian ini kriteria sampel masih belum maksimal dilakukan analisa untuk meminimalkan bias terhadap hasil penelitian. Perlu diperhaikan variabel 
I Putu Artha Wijaya: Hubungan Antara Stadium Kanker Payudara Terhadap Tingkat Depresi Pada Penderita Kanker Payudara Di Rsup Sanglah

perancu yang harus dikendalikan secara statistik.

\section{DAFTAR PUSTAKA}

Dyanti, G and et al.2016.Faktor-Faktor Keterlambatan Penderita Kanker Payudara Dalam Melakukan Pemeriksaan Awal Ke Pelayanan Kesehatan. Jurnal Kesehatan Masyarakat. Program Studi Kesehatan Masyarakat Fakultas Kedokteran Universitas Udayana : Denpasar

Hariroh, $\mathrm{N}$ and et al.2017.Hubungan Antara Tingkat Gejala Depresi Dengan Stadium Kanker Payudara Di Poli Onkologi Satu Atap (POSA) RSUD Dr. Soetomo Surabaya. Indonesian Journal Of Cancer Vol. 11 No. 1.Fakultas Kedokteran Universitas Airlangga : Surabaya

Hartaningsih, D et al.2012. Kanker Payudara Pada Wanita Usia Muda Di Bagian Bedah Onkologi Rumah Sakit Umum Pusat Sanglah Denpasar.Fakultas Kedokteran Universitas Udayana

Irawan, E et al.2017.Hubungan Dukungan Keluarga Dengan Kualitas Hidup Penderita Kanker Payudara.Jurnal Keperawatan BSI, Vol. 5, No. 2. Universitas BSI : Bandung

Keliat dan Akemat. 2010. Model Praktik Keperawatan Profesional Jiwa. Jakarta : EGC

Olfah, Y and et al.2013.Kanker Payudara Dan SADARI. Nuha Medika : Yogyakarta

Sari, A.2016.Tingkat Pengetahuan Wanita Usia Subur Tentang Kanker Payudara Di Wilayah Gonilan Sukoharjo. Akademi Kebidanan Mamba'ul Ulum Surakarta : Surakarta

Sari, M. (2014). Hubungan stadium kanker payudara dengan depresi di RSUD dr. Zainoel Abidin Banda Aceh. Savitri,A and et al.2015.Kupas Tuntas Kanker Payudara, Leher Rahim dan Rahim. Pustaka Baru Press : Yogyakarta

Sukma, D. M. (2018).Gambaran Tingkat Depresi pada Pasien Kanker Payudara yang Menjalani
Kemoterapi di Rumah Sakit Tingkat III Baladhika Husada Jember.

Widiyono,S.2017.Tingkat Depresi Pada Pasien Kanker Di RSUP Dr. Sardjito, Yogyakarta, Dan RSUD Prof.Dr. Margono Soekarjo, Purwokerto. Indonesian Journal Of Cancer Vol. 11, No. 4.Program Studi Magister Keperawatan Fakultas Kedokteran Universitas Gadjah Mada : Yogyakarta. 